\title{
Individual Political Behavior in Organizational Relationship
}

\author{
Abdul Latif \\ Department of Management Sciences, Abbasia Campus \\ The Islamia University of Bahawalpur, Punjab, Pakistan \\ E-mail: drabdullatif@hotmail.com \\ Zain Ul Abideen (Corresponding author) \\ Department of Management Sciences, Abbasia Campus \\ The Islamia University of Bahawalpur, Punjab, Pakistan \\ E-mail: zuabideen@gmail.com \\ Muhammad Suhail Nazar \\ Department of Management Sciences, Abbasia Campus \\ The Islamia University of Bahawalpur, Punjab, Pakistan \\ E-mail: suhail_nazar@yahoo.com
}

\begin{abstract}
This paper attempts to explain individual's political behaviour in organizations. It also suggests that as organization theory neglects individual's political behavior within organizations, so, individual political behavior in organizational context is explored using three key dimensions of political behaviors: internal-external, vertical-lateral and legitimate-illegitimate. A pattern based on these dimensions is proposed thus concluding that individual's practice politicking for a variety of reasons e.g. power, resources, knowledge, authority and securing their positions.
\end{abstract}

Keywords: Individual political behavior, Organizational theory, Dimensions of political behaviour

\section{Introduction}

It is generally believed that politics affect many decisions in life, although their intensity differs, but this fact cannot be denied that politics exists in workplace also. Different people describe workplace politics in diverse ways. Some people enjoy considering themselves as a part of those in power, while a lot of dread it, given that politics in workplace are not easy to deal with (Joan Marques, 2009). The May 2007 edition of HR Focus reports (HR Focus, 2007): "At heart, office politics involve jockeying for position in a workplace setting. While gossip in the workplace can be harmless, it becomes political when the goal is to gain advantage" (HR Focus, 2007, p. 8). The article further states: "Another sign that office politics are a problem is when important decisions are made without company-wide input" (HR Focus, 2007, p. 8).

Organizational politics are "those actions not officially approved by an organization taken to influence others to meet one's personal goals" (Greenberg and Baron, 1997) and would appear to be inevitable in organisational life (Susan Curtis, 2003). "Organizational politics have emerged in the last decade as a field of growing value and relevance for understanding managerial processes" (Vigoda, 2002, p. 571). Politicking is one of the options available for people who desire to influence decisions in organizations (Prasad, 1993). In any organization, it is not very difficult to find a person or group(s) indulging to influence decisions e.g. impression management and power coalitions etc. to either keep or supplement their personal interests, especially, if their organization is typified by uncertainty, lack of resources and lack of mutual conviction. Even though, organizational politics can work either for or against an organization, but sometimes it is called dysfunctional due to its potential power to disturb firm's efficiency and effectiveness (Kacmar et al., 1999).

Politics at whatever level is practiced in firms consumes time, confines information sharing and develops communication obstacles (Eisenhardt and Bourgeois, 1988). Any organizational life, which is prevalent with politics, is very stressful to work in, contribute less for promoting favourable job characteristics, and have high employee turnover (June M.L.Poon, 2003). Froman (1962) defined Political behavior in organizations "as those activities that are not required as part of one's organizational role but that influence, or attempt to influence, the distribution of advantages and disadvantages within the organization". This definition also highlights that individual political 
behavior in general may be enough to encompass different examples of organizational politics as whistle blowing, filing of grievances, using symbolic protest gestures, spreading rumors, leaking information to the media, disseminating ill news to keep someone under pressure and then ultimately gaining their interests, and at extreme filing lawsuits (Farrell \& Peterson, 1982).

Organizational politics is one of the central areas of research to scholars in organizational political framework (Habibollah Ranaei et al, 2010). Hartono et al., described that the shared information in organizational systems affects overall performance of the firm usually starting with top management support and IT infrastructure capabilities (Hartono et al, 2010). Weck \& Blomqvist, found informal and infrequent interorganizational relationships to be the primary source of external knowledge, in its place for formal partnerships having it's basis on contractual agreements (Weck \& Blomqvist, 2008). Organizational relations may be a source of obtaining many advantages, like access to new informational or knowledge resources (Choe, 2008) other resources such as HR, managerial and financial position, which are important conditions to fulfill customer needs and demands (kim et al., 2010) achieve comparative advantage (Dorrenbacher and Gammelgaard, 2010) lowering the costs of providing goods and services, and ultimately creating an environment of creativity and innovation (Doz, 1998).

Hoffman and scholsser (2001) have proposed that organizational relations may fill the fissure between firm's existing resources and future responsibilities. They will have to increase firm's competitive advantage via using external resources, synergy, developing a learning environment and rapid change. Many studies (Bacharach \& Lawler, 1980; Gandz \& Murray, 1980; Mayes \& Allen, 1977; Pfeffer, 1978, 1981; Tushman, 1977) have attempted to remedy the neglect of power and politics that scholars such as Mowday (1978) and Madison, Allen, Porter, Renwick, \& Mayes (1980) have seen as characteristic of the organizational literature. Despite the increase in consideration of politics, some factors of political phenomena continue to be overlooked in the organizational literature. This study bickers for the theoretical importance of individual political behavior while proposing three key dimensions of political behavior, and proposes a typology based on these dimensions.

\section{Conceptual Model}

For purposes of understanding organizational political behavior, we adopted Farrell and Peterson (1982) three-dimensional typology. The dimensions are:

- where the political activity takes place - inside or outside of the organization,

- $\quad$ the direction of the attempted influence -- vertically or laterally in the organization

- the legitimacy of the political action.

Insert Figure 1 (A) Here

\section{Literature Review}

Literature on organizational power and politics may be considered as a new area of politics in organizations. Issues related to inter-organizational power and politics were main areas of concerned to writers such as Weber and Michels (Farrell \& Peterson, 1982). After the development of scientific management, attention has been diverted to motivation and productivity. But, very rarely organizational scholars returned to the perspectives of power and politics e.g. March (1962) and Mechanic (1962) until the resurgence of such literature in the late 1970s. Harris et al. (2005) adopt Cropanzano's 1995 definition of organizational politics as, "social-influence attempts directed at those who can provide rewards that will help to promote or protect the self-interest of the actor" (p. 29). Ferris et al. (1996) view organizational politics as "behavior not formally sanctioned by the organization, which produces conflict and disharmony in the work environment by pitting individuals and/or groups against one another, or against the organization" (p. 234).

Ferris et al. (2007) draw more positive conclusions about workplace politics. They state: "The organizational-politics literature, frequently cast in a pejorative sense, has begun to recognize that politics are not necessarily inherently bad, and those who engage in influence do not always do so exclusively in a self-interested manner, and in direct opposition to organizational objectives" (p. 198). Sometimes, it is suspected that among the factors behind the revival of interest in organizational power and politics is the penetration of organizations by employees socialized into politics during the pro- tests of the 1960s. Further, political behavior in organizations recently has been highlighted against a societal background of decreasing trust in authority and by an increase in journalistic revelations of wrongdoing (Farrell \& Peterson, 1982).

Scholarly literature shows an increase in Marxist and conflict theories of organizations (e.g. special issue of Sociological Quarterly, winter, 1977). Pfeffer, observed that the dominant managerial perspective within organizational studies has neglected "one of the most important issues and activities that conflict in preferences among 
organizational participants and the resulting contest over the organization" (1978, p. 29). Moreover, various attacks e.g. March and Olsen (1976) and Weick (1979) on the goal approach and the general rational model of organizations may have made political models of organizations more relevant (Farrell \& Peterson, 1982).

The interest in organizational politics and power is comprised on several different work types. First, many authors (e.g. Butler, Hickson, Wilson, \& Axelson, 1977-78; Mayes \& Allen, 1977; Tushman, 1977) have supported that organizations be viewed as political arenas or have provided a conceptual framework to permit such an approach. Dachler and Wilpert (1978), although not explicitly concerned with politics, provided a conceptual framework for participation in organizations. The implications of participation for democratization and the diffusion of decision making suggest that this might also be seen as a call for political analysis. Secondly, the theme of power in organizations is receiving substantial attention. Power and organizational politics are linked theoretically and empirically to each other (Farrell \& Peterson, 1982).

Madison et al. study suggested that "the successful practice of organizational politics is perceived to lead to a higher level of power, and once a high level of power is attained, there is more opportunity to engage in political behavior" (1980, p. 94). Whereas, contemporary writers, in returning to the Weberian interests of power and authority, focused on bases of power (Salancik \& Pfeffer, 1974), loci of power (Madison et al., 1980), influence processes (Mowday, 1978 ) and the measurement of power. Power can be explained by linking it to environmental uncertainty and resource control (Farrell and Peterson, 1982). The organizational literature on power would benefit from Gamson's (1968) widely acclaimed synthesis of the social control and influence literatures. Although, studies of political behavior are not large in number. There are, however, studies of attributions of politicization and perceived organizational politics (Gandz \& Murray, 1980; Madison et al., 1980). Some studies also focused on group behavior, especially inter organizational power relations e.g. Salancik and Pfeffer (1974) and coalitions e.g. Bacharach and Lawler (1980).

Work on political behavior by individuals is limited although recent research on the filing of grievances (Dalton \& Todor, 1979; Muchinsky \& Maassarani, 1980) provides a good example. The relative neglect of individual political behavior in the current wave of interest in organizational research seems strange (Farrell \& Peterson, 1982). American values emphasis more on individualism and as a result heavy stress on individual behavior is quite natural. Many studies on organizational politics (Burns, 1962; Mechanic, 1962; Strauss, 1963) considered political actions taken by individual members of organizations. It is also acknowledged that the neglect of individual political behavior has three main basis: (1) failure to make a distinction between required job behavior / attitude from political behavior (2) unable to distinguish calculated from accidental political behavior, and (3) failure to distinguish clearly between macro and micro levels of analysis (Farrell \& Peterson, 1982).

Political behavior in terms of organizational context may be defined as facilitating the "non- rational influence on decision making" (Miles, 1980, p. 154) and existing as a "back-stage" doings (Burns, 1962, p. 260). On the other hand, definitions of organizational politics focuses on the exercise of power (Miles, 1980), the manipulation of influence (Madison et al., 1980), or the mobilization of resources in competition (Burns, 1962) do not make a clear distinction in political behaviors from those actions required while filling organizational positions. Acquiring of resources may result in practicing political behaviour. The Resource Dependency Theory (RDT) has its roots in open systems environment where organizations have to interact with their environment if they wish to get resources. According to this theory, necessary resource are those which are external or outside the business and almost every firm is dependent on external resources for its smooth functioning; this is the basic logic of "external interaction necessity" for an efficient firm. It put forwards that firms have to try to sustain and control, types of resources mentioned below, if they want to create and manage an effective interorganizational relationships.

1) Resource, which decrease organizational dependency to other organizations;

2) Resources, which increase other organizations dependency on them.

It seems that engaging in creating and maintaining effective organizational relationship is a path to maintain and actualize the points (Habibollah Ranaei et al, 2010). Mayes and Allen described in their study that "a suitable definition of organization politics must allow exclusion of routine job performance from consideration" (1977, $\mathrm{p}$. 674). Porter, Allen and Angle (1981) also eliminated behaviors, which are required or likely to occur, from their discussion of organizational politics, while treating political behavior as discretionary. They also believe that political behavior exist in informal structures and commune to the promotion of their own and group motives then being a part of formal rules and regulations which are regulated by organizational values and objectives. Moreover, analysis of political behaviors in organizations should focus on desired or overt actions by members while keeping in mind that unintended actions or even personal idiosyncrasies may have political effects (Farrell \& Peterson, 1982). 


\section{Individual Political Behavior}

Sometimes people show political behaviour to achieve their objectives, which are not going to be achieved otherwise, and they may indulge themselves in political behaviour to gain favors / benefits even at the cost of group benefits. They talk about different persons having power in the organizations, for gaining some benefits indirectly based on inter-organizational political behaviour. In addition to this, existing analyses of organizational politics may smudge the difference among different units of analysis by discussing the individuals' power, units and inter organizational political networks in the same phase. In their discussion, they may mix both macro and micro levels of analysis at the initial phase of dialogue, but sometimes, it is very difficult to assess the similarities or differences at each level of their discussion and any relation between them (Farrell \& Peterson, 1982).

Pfeffer $(1978,1981,1997)$ and Hardy \& Clegg (1996) may well succeed in their efforts to raise self-consciousness and refine theories of the organization and organizational learning to include attention to power and politics. It also looks suitable that the term political behavior should be put to one side for political actions of individual member of the organization (Farrell \& Peterson, 1982). Although organizational members widely acknowledged that political behaviour does exist in organizations, but efforts made to integrate them with organizational theory are not enough (Farrell \& Peterson, 1982). It has also been widely acknowledged by Political scientists and sociologists that one of the most principal political acts is the "personalized contact" (Verba, Nie \& Kim, 1971) whether it is for any social gain or any an individualized desired outcome.

Hirschman (1970) in his study referred to any social gain or an individualized interest as "voice" and confirmed that it could be applied with alike benefit in different social groups settings. Kolarska and Aldrich (1980) also redefined this "voice" by making a clear differentiation between indirect and direct "voice". He referred direct voice to "appeals to authorities within the focal organization" and indirect voice refers "to appeals to outside authorities or agents". Voting in many cases is necessary part of organizations' smooth functioning (Farrell \& Peterson, 1982). Zaleznik (1970) squabbles that sometimes the flow of funds and subordinate eagerness for management's projects may comprise referenda. Moreover, in many organizations the procedure of selecting top management and business control authority can be similar to each other under certain conditions (Lipset, Trow, \& Coleman, 1956). In individual political behaviour, whenever person failed to achieved his / her objectives, as problems and issues arise with internal procedures, then proxy fights and meeting room showdowns starts, then it recalls the organizational counterpart's ethical concerned committees to its investigations and proper reporting (Lipset, Trow, \& Coleman, 1956).

\section{Diversity in Political Behavior}

Farrell \& Peterson (1982) dimensions represents tactical choices which are made by organizational members in seeking resources or mobilizing existing / in hand resources to effect the sharing of advantages and disadvantages in inter organizational settings.

\section{Internal-External Dimension:}

\section{External}

- Whistle blowing

- Lawsuits

- $\quad$ Leaking information

\section{Internal}

- $\quad$ Exchange of favors

- Reprisals

- Obstructionism

- $\quad$ Symbolic protest

The internal-external dimension of political behavior is concerned with the focus of resources sought by those engaging in political behavior in organizations (Farrell \& Peterson, 1982). In cases, such as whistle blowing, lawsuits and leaking information to the media, organization members attempt to expand the resources available for mobilization by going outside the boundaries of the organization and attempting to involve "outsiders." Internal political behaviors, on the other hand, utilize resources which are already within the organization, as in the exchange of favors, trading agreements, reprisals, obstructionism, symbolic protest gestures, "touching bases," forming alliances with other organization members, riots and mutinies (Farrell \& Peterson, 1982). Kolarska \& Aldrich in their study reported, that appeals to interest groups outside the organization could be resorted to, due to many factors: 
People may use indirect voice when they feel that direct vice has failed and they are afraid of utilizing direct voice, sometimes may be due to not believing in the effectiveness or efficiency of using direct voice and finally when they do not know the appropriate way of using direct voice (1980, p. 44).

According to Weinstein, whistle blowing may be defined as "attempts to change a bureaucracy by those who work within the organization but do not have any authority" $(1979$, p. 2). Hierarchy in authority always play a leading role in most organizations and the proposed vertical-lateral dimension of political behavior identify the distinction between influence processes relating superiors to subordinates and those relating equals, and related political activities as complaining to a supervisor / management, bypassing the chain of command / authority, apple polishing and mentor protege activities, all can be best portrayed as vertical political behavior ( Farrell \& Peterson, 1980). Political behaviors also received comparatively less organized consideration but would include exchange of favors, help, organization of alliance, and discussion with an occupational senior outside the organization (Farrell and Peterson, 1980). The discussions between a leader and other people near to his / her organizational level, beyond the scope of their chain of command, sometimes are very critical but frequently neglected. Whatever the name it is called with, these discussions can fabricate discretion by making a more steady flow of diverse resources, thus lowering level of uncertainty and as a result increasing interdependency (Hunt \& Osborn, 1980, p. 57). Dalton's (1959) classic study of managers clarified the significance of discretionary lateral political behaviors. It is sometimes formal requirement for promotion of executives that they should have political abilities and skills other than having formal requirements because it "utilize and aid necessary cliques, and control dangerous ones" (Dalton, 1959, p. 181).

In discussing lateral relations among inbound agents of the organizations, Strauss, explained that "to some extent agents operate on the principle of 'reward your friends, punish your enemies,' and are involved in a network of exchange of favors-and sometimes even reprisals" (1963, p. 174). Lateral political actions may transpire at almost every level of organizations even though it looks like that persons at lower organizational level, lack considerable resources, may be motivated to augment their power and/or authority by adhering forces with seniors / management (Farrell and Peterson, 1982). Kolarska and Aldrich described in their study, that research in Poland "uncovered the existence of a set of moral norms regulating inter-organizational exchange. One norm concerned the impropriety of using forms of voice such as lawsuits, press leaks, and appeals to supervising organizations" (1980, p. 52). In political behaviors, which are generally acknowledged as legitimate would definitely include favors exchange, forming coalitions, and in quest of sponsors at top management levels (Farrell and Peterson, 1982). Similarly, less legitimate behaviors include whistle-blowing, revolutionary coalitions, menaces, and even sabotage e.g. during the Vietnam War, a new illegitimate activity gained substantial publicity i.e. the killing of officers in military units or "fragging" (Farrell and Peterson, 1982). Typically, legitimate politics is likely to be betrothed in by upper level management of organizations. Illegitimate political behavior is commonly defined as, actions taken by alienated members and those who observe that they will loss less comparatively (Farrell and Peterson, 1982).

\section{A Typology of Political Behavior}

A cross-tabulation of the three dimensions of political behavior (internal-external, vertical-lateral, and legitimate-illegitimate) help to develop the multidimensional typology of political behavior in organizations.

\section{Insert Figure 2 Here}

It produces an eight-celled matrix by cross classifying these dimensions (Farrell and Peterson, 1982). Regardless of the transformed interest in organizational power, authority and politics, no other system appeared that could explain the diversity and interrelationships of these behaviors. The typology proposed by Mayes and Allen (1977) structured organizational politics related to routine job behaviors was unable to deal with some particular political behaviors (Farrell and Peterson, 1982). Although, figure 1 is not comprehensive of all political actions taken in an organizations, but it include those structures of political behavior, which received either scholarly and /or journalistic consideration (Farrell and Peterson, 1982). It is also argued that the four dimensions / types of political behavior included in the "legitimate" category comprise the majority of all organizational political activities. Cell I behaviors include normal internal political behaviors which seems to be the most recurrent in organizations with hefty distinctions in benefits / rewards, and in organizations where sharing of decision-making process is limited (Farrell and Peterson, 1982). Obstructionism is generally a tactic used by those members who defy organizational policies through undue observance to rules and regulations (Farrell and Peterson, 1982). Sometimes members in lower level of organizations oppose or stand against top management when they observed that their participation in policymaking process is limited and these policies will ultimately affect them. Lateral political behaviors, discussed in Cell II are subject to increase under slack or not poorly managed control, if there is comparatively greater or equal positional power in non line-and-staff organizations (Cleland, 1967). 
External-vertical behaviors e.g. lawsuits or indirect voice (Cell III) commonly take place in areas where the legitimacy of conflict is established in sound way (Farrell and Peterson, 1982). However, there is also a need of such social set-ups where disputes in opinions or actions related to work environment can be resolved through peaceful discussion and mutual understanding. By using occupational and informal relations or liaison with outside the organization (Cell IV) members commonly put on access to information, power sharing, personal information and other resources (Farrell and Peterson, 1982). Sometimes maintaining liaison, although looks unnecessary, play key role in gaining legitimate rights that otherwise cannot be achieved in a smooth and timely manner. Illegitimate actions in whatever capacity and nature of can be a real threat in terms of loss of membership or even severe sanctions (Farrell and Peterson, 1982). Frequently, in organizations, members get them indulge in some sort of symbolic protests to get them realized by top management or to get them fulfilled their demands. Even in certain cases anarchic dress, button wearing, and "blue flu" can be diminutive appearances of organizational upheaval (Farrell and Peterson, 1982).

A variety of illegitimate behavior that, which has acquired a journalistic attention is whistle-blowing (Cell VII). It has also been called as "internal muckraking" (Peters \& Branch, 1972) which occurs when members of the organizations go public and disseminate to the media, the details of organizational delinquency, misbehavior, neglect or unreliability which make vulnerable interest of peoples associated with it. Organizational defections (Cell VIII) arise when executives / member(s) of top management either move to a competitor or start their own business, thus ditching loyalty to the parent business (Farrell and Peterson, 1982). In situations of organizational dishonesty or deceit, still, there is problem of dual membership and unpredictable or unreliable loyalties e.g. a devoted journalist who gets into "bunny ears" to write a first-rate story (Farrell and Peterson, 1982).

\section{Expected types of Political Behavior}

Handsome empirical studies for predicting the process through which individuals decide on the sort of political behavior they engage themselves in have not been conducted. An exchange framework, which allows certain predictable scenarios about such choices, is generally appropriate for studying of political behavior, as this theory put great emphasis on the person-organization association and emphasis on the distribution of limited resources. These four bases allow illustrating, from the viewpoint of organizational performer and the milieu of the political swap (Farrell and Peterson, 1982).

\section{Investments}

In investments, all those efforts and resources are include, which are committed by organizational members, to create and /or enhance strategic relationship with this hope that this relation will be a source of increase in future gain (Farrell \& Rusbult, 1981). Generally, workers become invested in a business as they get hands on non-portable training, experience, friendship and seniority as Becker (1960) describes, dwindle in an individual's tendency to quit a firm by escalating the cost associated with exit. It is believed that investments also reduce the chances of organizational member in illegitimate political behavior since such behavior keeps the investments at menace and there also exist anticipations of better results in the times to come (Farrell and Peterson, 1982).

In certain circumstances investments can be encouraged, Kolarska and Aldrich e.g. described the deeds of authorities who tried "to socialize the dissidents in- to the special organizational knowledge of the inner professional circle" (1980, p. 51). Investments also have the power of influencing the political behaviour of individual and firms as a whole. Vertical behavioral actions may be amplified i.e. Mechanic (1962) points out that as investments in specialized skills, fields and knowledge make dependence; so, in this way top-level members' power to technical staff is lessened. It also considerable that whenever levels of investment are high and handy in occupations or called by Thompson (1967) as "late-ceiling" occupations, where employees look for benefits by going outside the firms. In early-ceiling professions, individuals "seek leverage in the negotiation process through collective action" (Thompson, 1967, p. 113).

\section{Alternatives}

Alternatives are those opportunities, which may be availed if first options are otherwise not achieved. However, the quality of an individual's alternatives is enhanced, when there are some suitable labor market, the individual has obtained skills or knowledge in the demanding field, and when the individual puts much efforts in searching for alternatives. In certain organizations, either, alternatives do not exist or may be very limited. Employees, of company situated at remote place, may be imprisoned of their employers (Farrell and Peterson, 1982). Concisely, members of the organizations will not leave it, if alternatives are poor, but this tendency thus evokes the chances of internal protest / strikes. 
Hirschman discussed that "the voice option is the only way in which dissatisfied customers or members can react whenever the exit option is unavailable" $(1970$, p. 33). Sometimes alternatives are there, but remain unnoticed, because subjective perceptions play a vital role, and whenever there is unavailability of objective data. Another perceptual alteration takes places when alternatives are few: "a lack of alternatives raises people's perceived investments in an organization and increases the potential payoff of voice" (Kolarska \& Aldrich, 1980, p. 53). Many studies describe that when different opportunities are available, and each opportunity has different set of benefits or rewards, then individual member may exchange corporate membership for the risks and defy of independent entrepreneurship (Perrucci, Anderson, Schendel \& Trachtman, 1980; Wright, 1980). Forret and Dougherty (2001) described: "Gender, socio-economic background, self-esteem, extraversion, favorable attitudes toward workplace politics, organizational level, and type of position are significant predictors of involvement in networking behaviors" (p. 283).

Only a number of journalistic and legal studies reported, the cases where individuals in business firms and government agencies, regarded the public interest as overriding the firm's interest, they provided their services and decided to "blow the whistle" to notify public or legal authorities that their firms was involved in corruption, socially harmful actions, or illegal activities (Farrell and Peterson, 1982). While, there were inimitable aspects in each case, the whistle-blowers, seem to have had in general a strong sagacity of professional standards, an elevated level of personal self-esteem, and social guidance or support from his / her social circle, which enabled them to overcome both slightly pressures from concerned firms to remain "team players" and obvious challenges of blacklisting, social ostracism, and dismissal (Janis \& Mann, 1977, p. 273).

\section{Trust}

Trust may be defined as the apparent inevitability to influence (Gamson, 1968). In organizational context, when the lower level members hold high echelon of trust, they tend to believe that upper level management's actions will create favourable scenarios and required outcomes without taking any action by the lower level members. On the other hand, those who have low level of trust, hold no hope for having required results (Farrell and Peterson, 1982). Concept of trust, well acknowledged in literature of society and the state (Gamson, 1971; Miller, 1974), is also applicable to political behavior in organizational contexts. The salience of politics is concerned with the level of trust hold by organizational members: "If there is an extraordinarily high degree of trust, such as participants assuming that each is acting in each other's interests, then there need be little concern with issues of control and governance" (Pfeffer, 1978, p. 38). Trust always plays a key role in perception of organizational fidelity (Alutto \& Belasco, 1972; Buchanan, 1974; Spencer \& Steers, 1980). Sometimes, high level of trust among members of organizations, stimulate them to take extreme actions, because trust make them believe that everyone will help each other if something unfavorable happens.

It seems that level of members in organization determines the propensity of political behaviour, which definitely varies, as he/she moves from one stage to another in organization. Competition in certain cases also determines the levels of political behaviour implied in organizations. On the other hand, when there is lack of or lower level of trust exists among members, then it keeps them away to take extreme actions. Gamson points out, that "to point out to poor negroes in urban ghettos that riots are resented is a rather irrelevant communication to a group which feels there is little likelihood of obtaining favorable actions from authorities in the absence of such riots" (1968, p. 169). Away from, curbing the level of political behavior in common and stalling illegitimate deeds in meticulous, whatever the conditions, high trust level should lessen the vertical political behaviors (Farrell and Peterson, 1982). There can be a lack in leader's control to some recompenses, zero-sum situations, and organizational retrenchment can also produce lateral political behaviors still in conditions where high levels of trust exists (Farrell and Peterson, 1982).

\section{Efficacy}

Efficacy, as a common term may be defined as the perceived ability to influence (Gamson, 1968). Nevertheless, it does not refer to, the necessity to slot in political behavior, rather the anticipation that any member's political acts will produce required results. Self-efficacy level generally will be low, of the organizational members, who in the long run get them indulge in political behavior (Farrell and Peterson, 1982). There may be factors for gaining political behaviour by individual members in organizations: they may be new to the organization, it also include those who have changed either firms or departments within firm. So, these factors will intensify efforts to put on political behaviour in the business / firm If members feel that their efforts are useless, or perceived ability to influence is not expanded, then the level of political behaviour implied can be declined (Farrell and Peterson, 1982).

Organizational members can involve in external political behaviors generally, when they observe that it is impossible to have success through internal political process (Kolarska \& Aldrich, 1980). A member having low 
self-efficacy can go outside the firm having objectives to either look for further resources or in extreme actions to quit the firm (Farrell and Peterson, 1982). Hirschman described that "the decision whether to exit will often be taken in light of the prospects for the effective use of voice" (1970, p. 37). According to him, quitting can be a "last resort after voice has failed." It is also important that efficacy not only helps in forming the internal-external stream of political activities, but the procedure regarding the selection of legitimate or illegitimate course of actions related to political behaviors is affected also (Farrell and Peterson, 1982). Therefore, this scenario makes it clear that organizational members having high efficacy levels will have a propensity to employ legitimate political behaviors due to their interest in sustaining the firm, will cooperate in following the rules and regulations and also refrain from threatening the firm itself in any way (Farrell and Peterson, 1982).

\section{Discussion}

It is vital for every employee to get him/her know about the culture of the firm, he or she intended to join. "Many organizations have an obvious culture while they also harbor a deeper, less obvious mentality. It can be the obvious culture that attracts new members" (Joan Marques, 2009). Politics exists in organizations because many workplaces are still troubled by the "fiefdom" pattern, in which individuals have the view that their position are an asset and keep it safe, aggressively and jealously. "The psychological reason behind this pattern may be that society has taught us to define ourselves by our positions" (Joan Marques, 2009). So, in this way every member in the organizations protect their positions in whatever way they can, hence developing a "threat paranoia" (Joan Marques, 2009).

Brilliant and highly rated performance is not always appreciated and encouraged in every organization. May be, some members in the top management enjoy hard workers in his or her organization and may use the fruits of their hard work and talent toward the progress and development of whole firm, but, at the same time, remaining top management members can perceive talented and hard workers as a potential threat, and can do whatever they can to get rid of them early, hence the process of politics begins (Joan Marques, 2009).

\section{Implications}

Distinguishing existing views on organizational politics, Conner (2006) first illustrates some of the perceived advantages of organizational politics, in her statement, "organizational politics can have positive effects such as serving as a means for non-majority members to promote and accomplish their agenda"' (p. 718). Conner (2006) then presents a more neutral view about organizational politics, which states, "regardless of whether politics are positive or negative, they exist and should be explored" (p. 718). Conner concludes her overview of organizational politics with the dominant opinion: "for many people, organizational politics have very negative connotations and raise a number of ethical concerns. Hence, researchers see in the relevant literature descriptions of conflict over resources, self-serving behavior, and attempts to influence at the expense of others"' (p. 718).

While discussing political behavioral approach, a member pursues in organizations, a more rational rather than intuitive approach is more informative and suggested. Organizational theories backed up by the rational approach, even though they make available a valuable simplification of organizational reality, inevitably explain only a portion of the behavior that occurs. Organizational life involves contradictions because it encompasses two organizational realities: the rational and the political (Miles, 1980). Although, these two realities may involve contradictions, they frequently complement one another. Burns has observed that "members of a corporation are at one and the same time cooperators in a common enterprise and rivals for the material and intangible rewards of successful competition with each other" (1962, p. 258).

Identifying the internal-external, vertical-lateral, and legitimate-illegitimate dimensions of political behavior provides added insight to the current understanding of organizational behavior, and it offers options for future research. It now appears that research in the rational tradition seems to focus almost exclusively on internal legitimate political behaviors. As the typology presented here indicates, however, this hardly exhausts the range of political activity that may occur in organizations. The handful of existing studies that have looked at such phenomena as whistle-blowing (Parmerlee, Near \& Jensen, 1980; Perrucci et al., 1980), organizational dissent (Stanley, 1981), and organizational protest (Lipset, 1971), now may be more clearly related to the full range of political behavior in organizations.

Illegitimate political behaviors, though uncommon, provide a rich site for future research. The integration of a focus on political behavior in organizations with the rational model can enrich the understanding of such key organizational problems as effectiveness. The rational view always has assumed that efficient means-ends chains are the route to organizational effectiveness. The present authors believe that successful management of political activity in organizations is equally necessary for producing organizational effectiveness (Farrell and Peterson, 1982). In some instances, political activity is a precondition of rational administrative behavior. 
Bargaining has been shown to maintain organizational structure (Burns, 1962), and successful coalition formation within the executive structure, Zaleznik (1970) argues, helps avoid paralysis in decision-making. Political tactics also may serve as a direct managerial tool, as in Mowday's (1978) finding that selective filtering of information and exchanging favors were associated with high effectiveness among elementary school principals. Therefore, explaining the efficiency and effectiveness of the organization is closely linked with incorporating political variables. It is all about strategies and politics. Business, whether we admit it or not, thrives on politics. Only the strong survive.

\section{References}

Alutto, J. A. \& Belasco, J. A. (1972).A typology for participation in organizational decision making. Administrative Science Quarterly. 17: 117-125.

Bacharach, S. B. \& Lawler, E. J. (1980). Power and politics in organizations. San Francisco, Cal.: Jossey-Bass Publishing.

Becker, H. S. Notes on the concept of commitment. American Journal of Sociology. 1960, 66:32-40.

Buchanan, B. (1974).Building organizational commitment: The socialization of managers in work organizations. Administrative Science Quarterly. 19:533-546.

Burns, T. (1962).Micropolitics: Mechanisms of organizational change. Administrative Science Quarterly. 6:257-281.

Butler, R. J., Hickson, D. J., Wilson, D. C., \& Axelson, R. (1977-78).Organizational power, politicking and paralysis. Organization and Administrative Science. 8 (4): 45-49.

Cleland, D. I. (1967).Understanding project authority. Business Horizons, 10 (1), 63-70.

Choe J.M. (2008). Inter-organizational relationships and the flow of information through value chains, Information \& Management. 45: 444-450.

Conner, D.S. (2006), “Human-resource professionals' perceptions of organizational politics as a function of experience, organizational size, and perceived independence", The Journal of Social Psychology. 146(6): 717-32.

Dachler, H. P., \& Wilpert, B. (1978).Conceptual dimensions and boundaries of participation in organizations: A critical evaluation. Administrative Science Quarterly. 23: 1-39.

Dalton, M. Men who manage. New York: Wiley, 1959.

Dalton, D., \& Todor, W. D. (1979). Manifest needs of stewards: Propensity to file a grievance. Journal of Applied Psychology. 64:654-659.

Dorrenbacher, C, and Gammelgaard J. (2010). Multinational corporations, inter-organizational networks and subsidiary charter removals, Journal of World Business. 45:206-216.

Eisenhardt, K.M. and Bourgeois, L.J. III. (1988). "Politics of strategic decision making in high-velocity environments: toward a midrange theory", Academy of Management Journal. 31:737-70.

Farrell, D. J., \& Rusbult, C. E. (1981).Exchange variables as predictors of job satisfaction, job commitment, and turnover: The effects of rewards, costs, alternatives, and investments. Organizational Behavior and Human Performance. 28:78-95.

Ferris, G.R. et al. (1996). "Perceptions of organizational politics: prediction, stress-related implications, and outcomes", Human Relations. 49(2): 233-66.

Ferris, G.R., Zinkob, R., Brouerc, R.L., Buckleyd, M.R. and Harveye, M.G. (2007), "Strategic bullying as a supplementary, balanced perspective on destructive leadership", The Leadership Quarterly.18 (3):195-206.

Forret, M.L. and Dougherty, T.W. (2001). "Correlates of networking behavior for managerial and professional employees", Group \& Organization Management. 26(3): 283-311

Froman, L. A. (1962). People and politics. Englewood Cliffs, N. J.: Prentice Hall.

Gamson, W. A. (1968).Power and discontent. Homewood, Ill.: Dorsey.

Gamson, W. A. (1971).Political trust and its ramifications. In G. Abcarian \& J. Soule (Eds.), Social psychology and political behavior. Columbus, Ohio: Merrill, 40-55.

Gandz, J., \& Murray V. V. (1980).The experience of workplace politics. Academy of Management Journal. 23: 237-251.

Greenberg, J. and Baron, R.A. (1997), Behavior in Organizations, Prentice Hall, Englewood Cliffs, NJ. 
Habibollah Ranaei, Azim Zareei, Farshad Alikhani. (2010).Inter-organizational Relationship Management A Theoretical Model. International Bulletin of Business Administration. Issue 9:20-30.

Hirschman, A. O. (1970).Exit, voice and loyalty: Responses to decline in firms, organizations, and states. Cambridge, Mass.: Harvard University Press.

Hartono, E., Li, X., Na, K.S., Simpsonc, J. (2010). The role of the quality of shared information in inter organizational systems use, International Journal of Information Management. 30:399-407.

Harris, K.J., James, M. and Boonthanom, R. (2005), "Perceptions of organizational politics and cooperation as moderators of the relationship between job strains \& intent to turnover", Journal of Managerial Issues. 17(1): 26-42.

Hoffmann, W.H. \& Schlosser R. (2001). Success Factors of Strategic Alliances in Small and Mediumsized Enterprise. Long Range Planning. 34:357-381

HR Focus. (2007). "HR must handle productivity challenges from office politics", HR Focus. 84(5): 8-9

Hunt, J. G., \& Osborn, R. N. (1980).A multiple-influence approach to leadership for managers. In P. Hersey \& J. Stinson (Eds.), Perspectives in leadership effectiveness. Athens, Ohio: Ohio University Press, 47-62.

Hunt, J. G. \& Osborn, R. N. (1981).Towards a macro-oriented model of leadership: An odyssey. In J. G. Hunt, H. Sekaran, \& C. A. Schriesheim (Eds.), Leadership: Beyond establishment views. Carbondale, Ill.: Southern Illinois University Press, 196-221.

Janis, I. L. \& Mann, L. (1977).Decision making. New York: Free Press.

Joan Marques. (2009). Organizational politics: problem or opportunity?, Human Resource Management International Digest. 17(6):38-41

June M.L. Pune. (2003). "Situational antecedents and outcomes of organizational politics perceptions". Journal of Managerial psychology. 18(2):138-155

Kacmar, K.M., Bozeman, D.P., Carlson, D.S. and Anthony, W.P. (1999). "An examination of the perceptions of organizational politics model: replication and extension", Human Relations. 52:383-416

Kim, K.K, Park, S.H, Ryoo, S.Y, Park, S.K. (2010). Inter-organizational cooperation in buyer-supplier relationships: Both perspectives, Journal of Business Research. 63: 863-869.

Kolarska, L. \& Aldrich, H. (1980).Exit, voice, and silence: Consumers' and managers' responses to organizational decline. Organization Studies. 1:41-58.

Lipset, S. M. (1971).Rebellion in the university. Boston: Little, Brown \& Co.

Lipset, S. M., Trow, M. \& Coleman, J. (1956).Union democracy. Glencoe, Ill.: The Free Press, 1956.

Madison, D. L., Allen, R. W., Porter, L. W., Renwick, P. A. \& Mayes, B. T. (1980). Organizational politics: An exploration of managers perceptions. Human Relations. 33:79-100

Farrell \& Peterson, (1982).Patterns of Political Behaviour in Organizations. Academy of Management Review. 7(3): 403-412

March, J. G. (1962).The business firm as a political coalition. Journal of Politics. 24: 662-678.

March, J. G. \& Olsen, J. P. (1976).Ambiguity and choice in organizations. Bergen, Norway: Universitetsforlaget.

Martin, N. H., \& Sims, J. H. (1974).Power tactics. In D. A. Klog, I. M. Rubin, \& J. M. McIntyre (Eds.) Organizational psychology. 2nd ed. Englewood Cliffs, N. J.: Prentice-Hall.

Mayes, B. T., \& Allen, R. W. (1977).Toward a definition of organizational politics. Academy of Management Review. 2: 672-678.

Miles, R. H. (1980). Macro organizational behavior. Santa Monica, Cal.: Goodyear Publishing, 1980.

Miller, A. H. (1974).Political issues and trust in government. American Political Science Review. 68: 951-972.

Mowday, R. T. (1978).The exercise of upward influence in organizations. Administrative Science Quarterly. 23: 137-156.

Muchinsky, P. M. \& Maassarani, (1980).M. A. Work environment effects on public sector grievances. Personnel Psychology. 33:403-414.

Prasad, L. (1993). "The etiology of organizational politics: implications for the entrepreneur", SAM Advanced Management Journal. 58(3):35-41. 
Parmerlee, M. A., Near, J. P., \& Jensen, T. C. (1980).Correlates of whistle blowers' perceptions of organizational reprisal. Working paper, Indiana University.

Perrucci, R., Anderson, R. M., Schendel, D. E., \& Trachtman, L. E. Whistle-blowing: Professionals' resistance to organizational authority. Social Problems. 1980, 28:149-164.

Peters, C., \& Branch, T. (1972).Blowing the whistle. New York: Praeger.

Pfeffer, J. (1978).The micropolitics of organizations. In Marshall Meyer \& Associates (Eds.), Environments and organizations. San Francisco: Jossey-Bass: 29-50.

Pfeffer, J. (1981). Power in organizations. Boston, Mass.: Pitman Publishing.

Pfeffer, J. (1997). New Directions for Organizational Theory. New York: Oxford University Press

Porter, L. W., Allen, R. W., \& Angle, H. L. (1981). The politics of upward influence in organizations. In L. L. Cummings \& B. M. Staw (Eds.), Research in organizational behavior. 3, Greenwich, Conn.: JAI Press.

Salancik, G. R. \& Pfeffer, J. (1974). The cases and uses of power in organizational decision-making: The case of a university. Administrative Science Quarterly. 19: 453-473.

Spencer, D. G. \& Steers, R. M. (1980). The influence of personal factors and perceived work experiences on employee turnover and absenteeism. Academy of Management Journal. 23:567-572.

Stanley, J. E. (1981). Dissent in organizations. Academy of Management Review. 6:13-19.

Strauss, G. (1963). Tactics of lateral relationship: The purchasing agent. Administrative Science Quarterly. 1:161-185.

Susan Curtis. (2003). Lies, damned lies and organisational politics. Industrial and Commercial Training. 35(7): 293-297

Thompson, J. D. Organizations in action. New York: McGraw- Hill, 1967.

Tushman, M. L. (1977). A political approach to organizations: A review and rationale. Academy of Management Review. 2:206-216.

Verba, S., Nie, N. H., \& Kim, J. O. (1971). The modes of democratic participation: A cross-national comparison. Beverly Hills, Cal.: Sage Publications.

Vigoda, E. (2002). Stress-related aftermaths to workplace politics: the relationships among politics, job distress, and aggressive behavior in organizations, Journal of Organizational Behavior. 23(5):571-91

Weck M, Blomqvist K. (2008). The role of inter-organizational relationships in the development of patents: A knowledge-based approach, Research Policy. 37:1329-1336.

Weick, K. E. (1979). The social psychology of organizing. 2nd ed. Reading, Mass.: A. Wesley Publishing Co.

Weinstein, D. (1979). Bureaucratic opposition. New York: Pergamon Press.

Wright, J. P. (1980). On a clear day you can see General Motors: John Z. DeLorean's look inside the automotive giant. Ossining, New York: Carolina House.

Zaleznik, A. (1970). Power and politics in organizational life. Harvard Business Review. 48 (3):47-60. 


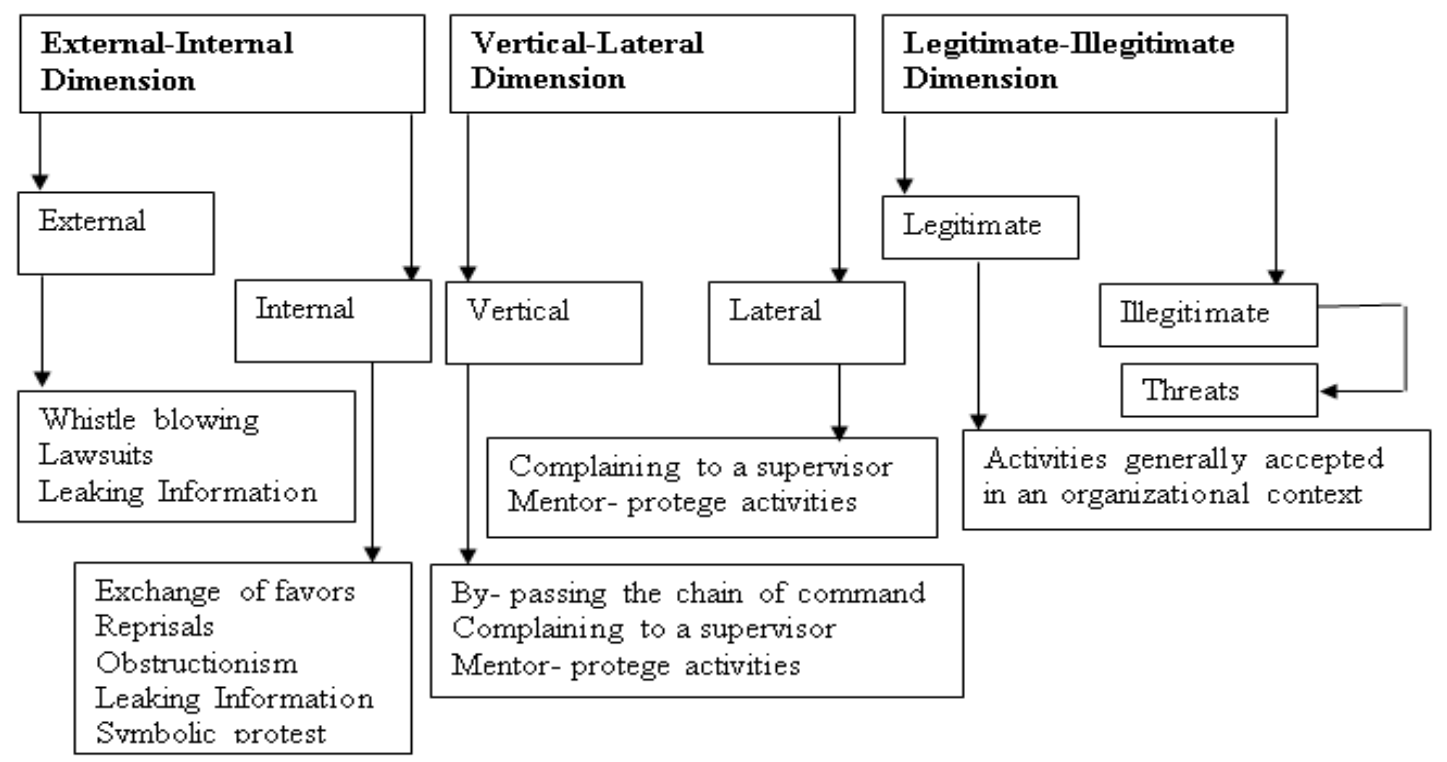

Figure 1 (A): Conceptual Model

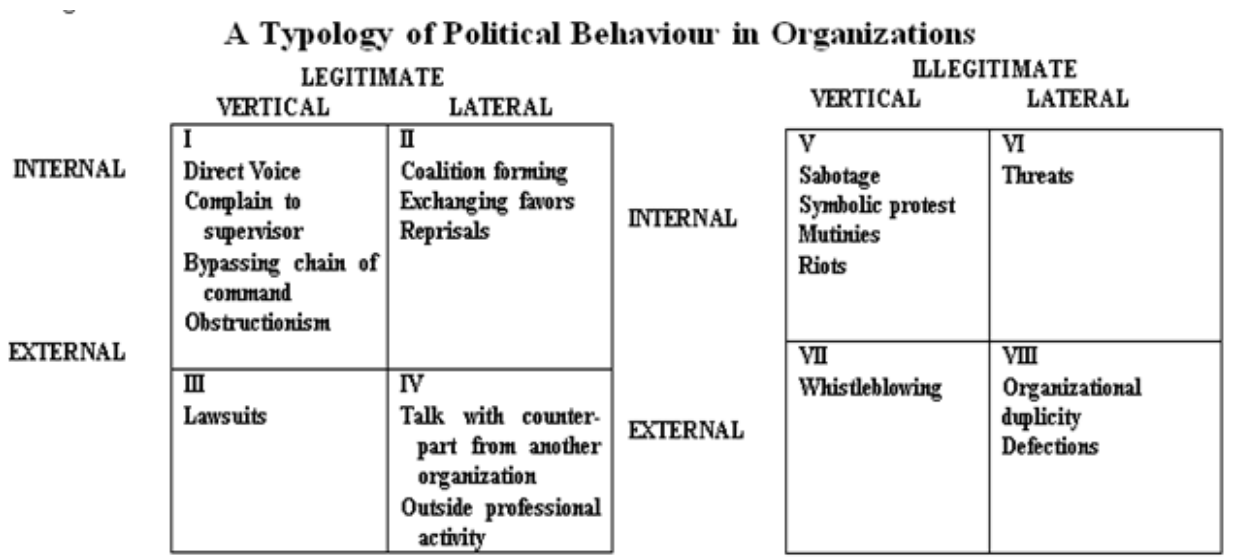

Figure 1. 